Journal of Food Technology 9 (1): 1-8, 2011

ISSN: $1684-8462$

(C) Medwell Journals, 2011

\title{
Comparison of PCR-DGGE and PCR-SSCP Analysis for Microflora of Kaburazushi and Daikonzushi, Traditional Fermented Foods Made from Fish and Vegetables
}

\author{
Choa An, Hajime Takahashi, Bon Kimura and Takashi Kuda \\ Department of Food Science and Technology, \\ Tokyo University of Marine Science and Technology, \\ Minato-Ku, 108-8477 Tokyo, Japan
}

\begin{abstract}
Kaburazushi and daikonzushi are traditional lactic acid fermented foods made in the Hokuriku area of Japan. In kaburazushi processing, salted turnip (Brassica rapa var. glabra) and salted yellowtail (Seriola quinqueradiata $)$ are fermented with malted rice for several days to 2 weeks in winter $\left(0-10^{\circ} \mathrm{C}\right)$. Daikonzushi is made from Japanese white radish (Raphanus sativus var. raphanistroides), dried and leached Pacific herring (Clupea pallasi) and malted rice processed the same as for kaburazushi. To clarify the microbial property for the processing and human health, researchers employed a molecular approach to analyze the bacterial flora of kaburazushi and daikonzushi and their ingredients, combining PCR amplification of the V3 region of the 16S rDNA gene and Denaturing Gradient Gel Electrophoresis (DGGE) analysis. Furthermore we identified the isolated strains using PCR-Single Strand Conformation Polymorphism (SSCP) analysis. In the PCR-DGGE analysis, Lactobacillus sakei was detected as the predominant bacteria in both products. On the other hand, the bacterial DGGE band was not detected in salted turnip and salted yellowtail. L. sakei and Leuconostoc mesenteroides were isolated and identified as the predominant lactic acid bacteria in the products by PCR-SSCP analysis. The halo-tolerant bacteria Staphylococcus gallinarum was also isolated and identified.
\end{abstract}

Key words: Kaburazushi, daikonzushi, Denaturing Gradient Gel Electrophoresis (DGGE), Single Strand Conformation Polymorphism (SSCP), Lactobacillus sakei, Leuconostoc mesenteroides

\section{INTRODUCTION}

In modern Japanese cuisine, sushi is made from vinegar flavored rice combined with seafood. It is thought that sushi originates from the salted and long-fermented fish called narezushi in Japan. The earliest reference to sushi appeared in a code named the Yoro-Ritsuryo issued in $\mathrm{AD} 718$ and this earliest sushi is postulated to have been narezushi (Ichishima, 2004). Since that time, narezushi products have been made from various fishes in several areas located inland rather than in coastal regions. Funazushi, a fermented crucian carp with cooked rice made near Lake Biwa, located in central Japan is the most famous narezushi, characterized by its strong flavors and odors. Fujii et al. (2008) reported that funazushi is a typical lactic acid fermented product.

Kaburazushi and daikonzushi are traditional fermented foods made in the Hokuriku area of Japan (Nakazawa, 1983). Historically, lactic acid fermented foods were thought to have been derived from narezushi since the Edo era (AD 1600-1860). In kaburazushi processing, fish and cylindrical formed turnips (Brassica rapa var. glabra) are salted and individual salted fish slices are placed within the salted turnip channels. The prepared materials are then fermented with rice malted with Aspergillus oryzae ( $\mathrm{koji}$ ) in a barrel for a period of several days to 2 weeks in winter $\left(0-10^{\circ} \mathrm{C}\right)$. While daikonzushi is made from Japanese white radish, dried and leached herring and koji, it is processed the same as for kaburazushi.

It is well known that Lactic Acid Bacteria (LAB) in fermented foods affect not only product quality 20 and preservation (Riebroy et al., 2008; Lore et al., 2005) but also food functionality, such as improving 21 the intestinal environment in a manner similar to probiotics (Vinderola et al., 2008; Guo et al., 2009; Pennacchia et al., 2006), immune and antiallergic activities (Masuda et al., 2008; Vinderola et al., 2007) and anti-hypertensive effects (Kilpi et al., 2007). Recently, a high content of Gamma Aminobutyric Acid (GABA) was detected in kaburazushi (Aida and Sumino, 2007). Production of GABA by type strains of $\mathrm{LAB}$ in cluding isolates from traditional

Corresponding Author: Takashi Kuda, Department of Food Science and Technology,

Tokyo University of Marine Science and Technology, Minato-Ku, 108-8477 Tokyo, Japan 
fermented foods was reported (Komatsuzaki et al., 2005). Determination of the microflora of kaburazushi and daikonzushi using culture methods has been reported (Aida and Sumino, 2007; Kuda et al., 1998). During fermentation there is an increase in LAB and lactic acid and a decrease in $\mathrm{pH}$ (4.2 and lower). However, the microflora has not yet been clearly identified at the level of genus and species.

Due to the known limitations of cultivation methods many recent studies have used culture independent $16 \mathrm{~S}$ rDNA-based PCR techniques (Singh et al., 2009) including PCR-Denaturing Gradient Gel Electrophoresis (DGGE) and PCR-Single Strand Conformation Polymorphism (PCR-SSCP) to determine the microflora of various traditional fermented foods (Chamkha et al., 2008; Chen et al., 2008; Kim et al., 2009). In this study, to clarify the microbial property for processing and human health we investigated the bacterial flora of kaburazushi and daikonzushi and their ingredients using a molecular approach, combining PCR amplification of the $\mathrm{V} 3$ region of the 16S rDNA gene and DGGE. Furthermore, researchers identified the isolated strains using PCR-SSCP.

\section{MATERIALS AND METHODS}

Kaburazushi and daikonzushi samples: The fermented products kaburazushi and daikonzushi (Fig. 1) and their materials, were kindly provided by Shijimatya-Honpo Co. (Kanazawa, Ishikawa, Japan) in December 2008. Prior to fermentation processing (Fig. 2), turnip (Brassica rapa var. glabra) and Japanese white radish (Raphanus sativus var. raphanistroides) were salted for 3 days (shitazuke) and the yellowtail (Seriola quinqueradiata) was salted for 1 year. Dried pacific herring (Clupea pallasi) was leached in clean water overnight. Rice malted with Aspergillus oryzae (koji) was emulsified with cooked rice and water (amazake, saccharified rice gruel) before use. The fermentation was carried out at ambient temperature $\left(0-10^{\circ} \mathrm{C}\right)$ for 1 week (honzuke).

Chemical analysis: Salinity, $\mathrm{pH}$ and organic acids of the samples were determined using methods cited in the previous reports (Kuda et al., 2009, 2010).

Microbiological analysis and collection of isolates and cell mixtures: Samples $(25 \mathrm{~g})$ were emulsified in $225 \mathrm{~mL}$ of sterile phosphate buffer (PBS, $20 \mathrm{mM} \mathrm{KH}_{2} \mathrm{PO}_{4}-0.01 \mathrm{M}$ $\mathrm{K}_{2} \mathrm{HPO}_{4}, \mathrm{pH}$ 7.2) and blended for $60 \mathrm{sec}$ (Stomacher 400 , Seward, London, UK). The sample suspensions were diluted in PBS and appropriate dilutions were spread in duplicate on Tryptone Soy (TS) agar (Oxoid, Basingstoke,
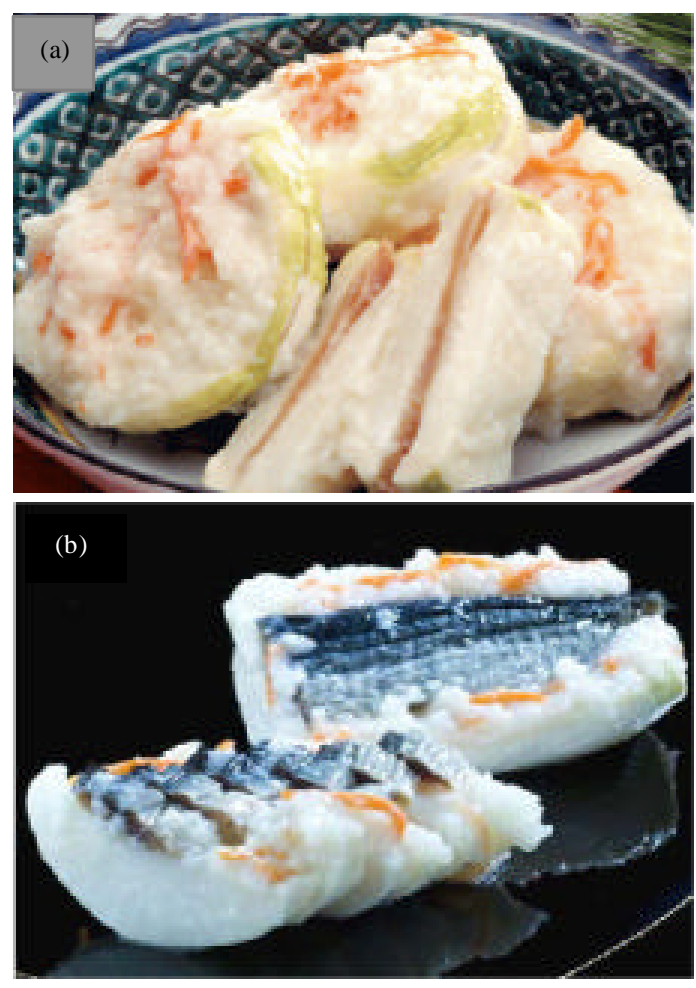

Fig. 1: Fermented products, (a) kaburazushi and (b) daikonzushi

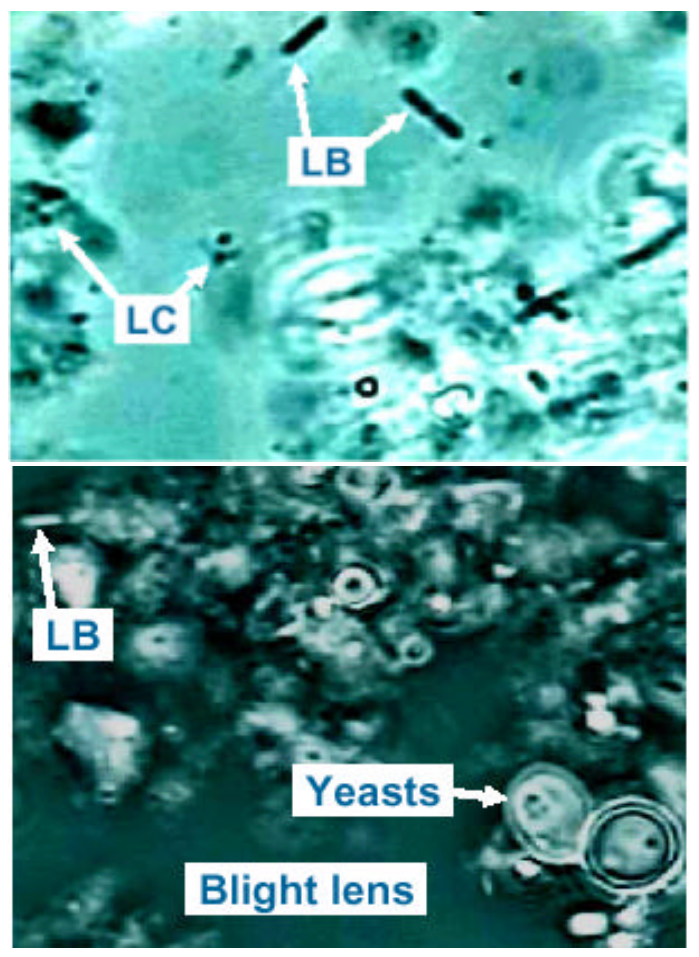

Fig. 2: Production processes of kaburazushi and daikonzushi 
UK), TS agar containing 10\% (w/v) $\mathrm{NaCl}$ and de Man, Rogosa and Sharpe (MRS) agar plates (Oxoid). TS agar plates were aerobically incubated at $30^{\circ} \mathrm{C}$ for $2-4$ days. MRS agar plates were anaerobically incubated at $30^{\circ} \mathrm{C}$ using an AnaeroPack system (Mitsubishi Gas Chemical, Tokyo, Japan) for 5-7 days. About 25 colonies from each sample were picked and re-streaked for purification prior to PCR-SSCP analysis.

Direct extraction of DNA and PCR amplification: DNA from $1 \mathrm{~mL}$ of homogenate per sample and the isolates was extracted using FastPure DNA Kit (Takara, Otsu, Japan). Purified DNA was dissolved in TE buffer and used as the DNA template in PCR.

The following primer pair was chosen for the amplification of the $\mathrm{V} 3$ region $(-220 \mathrm{bp})$ of the $16 \mathrm{~S}$ rRNA gene: forward primer with GC clamp (Sheffiedld et al., 1998) GC-339f (5'-CGC CCG CCG CGC CCC GCG CCC GTC CCG CCG CCC CCG CCCGCT CCT ACG GGA GGC AGC AG-3') and reverse primer V3-53r (5'-GTA TTA CCG CGG CTG CTG G-3'). PCR amplification was performed in $100 \mu \mathrm{L}$ reaction mixtures composed of $10 \mathrm{mM}$ Tris- $\mathrm{HCl}(\mathrm{pH}$ 8.3) $50 \mathrm{mM} \mathrm{KCl}_{1} 1.5 \mathrm{mM} \mathrm{MgCl}_{2}, 50$ pmol each of primer, $0.2 \mathrm{mM}$ each of $4 \mathrm{dNTPs}, 2.5 \mathrm{U}$ of Takara Taq DNA polymerase (Takara Bio, Shiga, Japan) and $50 \mathrm{ng}$ of template DNA. To minimize amplification of nonspecific products and to obtain large amounts of PCR products, touchdown PCR (Don et al., 1991) was performed where the initial annealing temperature was set at $8^{\circ} \mathrm{C}$ above the expected annealing temperature and decreased by $0.8^{\circ} \mathrm{C}$ every second cycle until the expected annealing temperature $\left(62^{\circ} \mathrm{C}\right)$ was reached (total 20 cycles) and then 5 additional cycles were carried out. Amplification was carried out using the following cycle: denaturation at $94^{\circ} \mathrm{C}$ for $30 \mathrm{sec}$, annealing for $30 \mathrm{sec}$ and primer extension at $72^{\circ} \mathrm{C}$ for $10 \mathrm{sec}$ in a GeneAmp 97004 thermal cycler (Applied Biosystems, Foster City, CA, USA). Aliquots ( $5 \mu \mathrm{L}$ ) of the PCR products were analyzed first by electrophoresis in $2 \%(\mathrm{w} / \mathrm{v})$ agarose gels.

DGGE analysis of PCR products: DGGE analysis of $P C R$ amplification products was performed as previously described (Muyzer et al., 1993), using the DCode System apparatus (Bio-Rad Laboratories, Hercules, CA, USA). Polyacrylamide gels $(8 \%(\mathrm{w} / \mathrm{v})$ acrylamide-bisacrylamide (37.5:1)) in $1 \times$ Tris-acetate-EDTA buffer with a denaturing gradient ranging from $30-60 \%$ denaturant $(100 \%$ denaturation corresponds to $\mathrm{M}$ urea and $40 \%(\mathrm{v} / \mathrm{v})$ formamide) was prepared with the Bio-Rad model 475 gradient delivery system. Polymerization was achieved by adding $0.9 \%(\mathrm{v} / \mathrm{v})$ ammonium persulfate (10\% solution) and $0.09 \%(\mathrm{v} / \mathrm{v}) \mathrm{N}, \mathrm{N}, \mathrm{N}, \mathrm{N}$-tetra methyl ethylene diamine.
The gels were electrophoresed at a constant voltage of $200 \mathrm{~V}$ at $60^{\circ} \mathrm{C}$ for $3 \mathrm{~h}$. The DNA fragments were stained with ethidium bromide and washed with distilled water prior to UV transillumination.

The main DGGE fragments were selected for nucleotide sequence determination. Each band was excised with a sterile razor. The DNA of each fragment was eluted in $50 \mu \mathrm{L} \mathrm{TE}$ buffer at $100^{\circ} \mathrm{C}$ for $10 \mathrm{~min}$. The extracts were re-amplified by PCR using the same primers and purified with SUPREC-PCR (Takara) according to the manufacturer's instructions. Purified DNA fragments were ligated in pT7blue-vectors (Novagen, Darmstadt, Germany) and transformed into $E$. coli JM109. The transformants were grown up on LB agar containing ampicillin and screened by galactosidase assay. Plasmid DNA of selected transformants was isolated using a Plasmid miniprep kit (Bio-Rad). The inserted DNA sequence, approximately 200 bp of $16 \mathrm{~S}$ rDNA ( $E$. coli position 389-530) (Neefs et al., 1990) was determined using a 3130 Genetic Analyzer (Applied Biosystems) with the Big Dye Terminator V3.1 Cycle Sequencing Kit (Applied Biosystems). To identify the inserted sequences, the BLAST 2.0 algorithm was used to compare the derived sequence to $16 \mathrm{~S}$ rDNA sequences in the DNA Data Bank of Japan (DDBJ) 3 database. The DGGE analysis was done repeatedly 3 times.

PCR-SSCP analysis of $16 \mathrm{~S}$ rDNA V3 region: In the PCR-SSCP analysis, we used precast polyacrylamide gels followed by silver staining because of the high sensitivity of silver staining. This method visualizes even a small amount of nonspecific amplification product; therefore, several PCR primers and thermal profiles were tested for specificity and differences in PCR efficiency. The primer set, SRV3-1 (5'- CGG YCC AGA CTC CTA CGG G-3') (Lee et al., 1996) as the forward primer and V3R53 (5'-GTA TTA CCG CGG CTG CTG GC-3') which was designed based on 536R (Weisburg et al., 1991) with minor modifications as the reverse primer gave acceptable results. PCR amplification was performed in $100 \mu \mathrm{L}$ reaction mixtures composed of $10 \mathrm{mM}$ Tris- $\mathrm{HCl}(\mathrm{pH} 8.3)$, $50 \mathrm{mM} \mathrm{KCl}, 1.5 \mathrm{mM} \mathrm{MgCl}, 50 \mathrm{pmol}$ each of primer, $0.2 \mathrm{mM}$ each of $4 \mathrm{dNTPs}, 2.5 \mathrm{U}$ of Takara Taq DNA polymerase (Takara Bio, Shiga, Japan) and $50 \mathrm{ng}$ of template DNA. In this analysis, touchdown PCR was also performed; the initial annealing temperature was set at $6^{\circ} \mathrm{C}$ above the target annealing temperature and decreased by $0.6^{\circ} \mathrm{C}$ every second cycle until the target annealing temperature $\left(61^{\circ} \mathrm{C}\right)$ was reached and then additional cycles were carried out with the target annealing temperature. Amplifications were carried out in a GeneAmp 9700 thermal cycler (Applied Biosystems) using 
the following cycle: denaturation at $94^{\circ} \mathrm{C}$ for $30 \mathrm{sec}$, annealing at the temperature regime described above for $30 \mathrm{sec}$ and primer extension at $72^{\circ} \mathrm{C}$ for $10 \mathrm{sec}$ for touchdown cycles and $72^{\circ} \mathrm{C}$ for $30 \mathrm{sec}$ for the last 5 additional cycles.

SSCP analysis of PCR products was performed as described previously (Takahashi et al., 2004). Briefly, PCR products were mixed 1:2 with loading buffer $(98 \%$ formamide-10 $\mathrm{mM}$ EDTA-0.5\% bromophenol blue), denatured by heating for $10 \mathrm{~min}$ at $100^{\circ} \mathrm{C}$, cooled on ice, loaded in a precast, ready-to-use gel (GeneGel Excel 12.5/24 kit; GE Healthcare) and electrophoresed on a GenePhor electrophoresis unit (GE Healthcare) at $650 \mathrm{~V}$, $25 \mathrm{~mA}$ and $5^{\circ} \mathrm{C}$ until the bromophenol blue front reached the anode buffer strip (about $90 \mathrm{~min}$ ). The gel was stained with PlusOne DNA silver staining kit (GE 3Healthcare). Scanned photographs of SSCP gels were stored as TIFF images.

\section{RESULTS AND DISCUSSION}

Salinity, pH value and organic acids: Table 1 shows salinity, $\mathrm{pH}$ and organic acid content of the samples. Salinity of the products was about $3 \mathrm{~g} / 100 \mathrm{~g}$. The predominant organic acid in the samples was lactic acid with other organic acids at very low levels; the lactic acid content in the fermented products was $4.3-4.6 \mathrm{mg} \mathrm{g}^{-1}$. The $\mathrm{pH}$ value of the kaburazushi and daikonzushi products was 4.4 and 5.0,11, respectively. These results agree with the previous reports (Kuda et al., 1998, 2010).

Viable plate count: In direct observation using phase-contrast microscope, lactobacilli, lactococci and yeasts were detected (Fig. 3). Viable plate counts of the kaburazushi and daikonzushi samples are shown in Table 1. The LAB count (on MRS agar) of both products was very high, approximately 8.8 and $8.9 \log \mathrm{cfu} \mathrm{g}^{-1}$ for kaburazushi and daikonzushi, respectively. This result is in agreement with the previous report (Kuda et al., 1998). The LAB counts of amazake and herring were low, approximately 3.5 and $4.0 \log \mathrm{cfu} \mathrm{g}^{-1}$, respectively while viable counts on TS agar were high, approximately 6.3 and 7.3 , respectively. Interestingly, the LAB count was already high in salted turnip $\left(6.8 \log \mathrm{cfu} \mathrm{g}^{-1}\right)$ while the count in salted radish was low $\left(-2.8 \log \mathrm{cfu}^{-1}\right)$. The viable count in the long salted yellowtail was very low and was not detected on TS agar plates.

Bacterial flora analyzed by PCR-DGGE method: For DGGE analysis, researchers selected the V3 region of $2416 \mathrm{~S}$ rDNA as the target region. This region has been widely used in the analysis of bacterial community or the identification of isolated bacteria (Chen et al., 2008; Ercolini et al., 2003). PCR products originating from sample preparations were divided into one to four main fragments by DGGE analysis (Fig. 4) with the banding patterns differing by sample. Subsequently, to identify the main bands, each band was recovered from the DGGE-gel and sequenced. The results obtained from clone sequencing are 5 (Table 2 ).

In the case of amazake, three of the four bands detected were identified as Bacillus subtilis with the remaining band unidentified as rice Oryza sative. A single band was clearly detected in salted turnip and 8 was identified as turnip Brassia rapa. In the case of DGGE analysis for fermented plant foods, the chloroplast was detected as main band in early fermentation stage (Miambi et al., 2003; Nakayama et al., 2007; Ben-Omar and Ampe, 2000). No band was detected in salted yellowtail. The typical marine bacterium Shewanella baltica was detected in salted radish and dried-leached herring. $S$. baltica has been reported to be the most important $\mathrm{H}_{2} \mathrm{~S}$-producing species during iced storage of Danish marine fish (Vogel et al., 2005). Lactobacillus sakei was predominantly detected in both kaburazushi and daikonzushi. L. sakei is moderately halo-tolerant and has been isolated from traditional fermented foods such as fermented sausage (Fontan et al., 2007; Ammor et al., 2005). There are several reports dealing with bacteriocins produced by L. sakei (Urso et al., 2006). Gao et al. (2010) reported on a novel bacteriocin with a broad inhibitory spectrum produced by L. sakei.

Table 1: Chemical compounds and viable counts of ingredients and finished products of kaburazushi and daikonzushi

\begin{tabular}{|c|c|c|c|c|c|c|c|}
\hline \multirow[b]{2}{*}{ Culture media } & \multirow[b]{2}{*}{ Amazake (koji) } & \multicolumn{3}{|c|}{ Kaburazushi } & \multicolumn{3}{|c|}{ Daikonzushi } \\
\hline & & Turnip* & Yellowtail** & Product & Radish* & Herring *** & Products \\
\hline $\mathrm{NaCl}(\mathrm{g} / 100 \mathrm{~g})$ & 0.2 & 4.2 & 11.6 & 2.80 & 6.0 & 0.4 & 3.30 \\
\hline $\mathrm{pH}$ & 5.3 & 5.5 & 6.0 & 4.40 & 5.7 & 6.6 & 5.00 \\
\hline \multicolumn{8}{|l|}{ Organic acids (mg g-1) } \\
\hline Lactic acid & NT & 0.55 & NT & 4.69 & ND & NT & 4.33 \\
\hline Acetic acid & NT & 0.49 & NT & 1.95 & 0.24 & NT & 0.71 \\
\hline \multicolumn{8}{|l|}{ Viable counts (log cfu $\mathrm{g}^{-1}$ ) } \\
\hline TS agar & 6.30 & 6.85 & $\mathrm{ND}$ & 6.70 & 3.90 & 7.30 & 8.85 \\
\hline $\mathrm{TS}+10 \%(\mathrm{w} / \mathrm{v}) \mathrm{NaCl}$ agar & 5.30 & 3.95 & ND & 5.30 & 3.00 & 5.95 & 3.30 \\
\hline MRS agar & 3.48 & 6.78 & 2.60 & 8.78 & 2.78 & 4.00 & 8.90 \\
\hline
\end{tabular}

Values are mean of duplicate measurement. ND: Not Detected. NT: Not Tested. TS agar: Non-selective medium; TS+10\%(w/v) NaCl agar: For halophilic bacteria; MRS agar: For lacticic acid bacteria. *Salted:***Dried and leached 


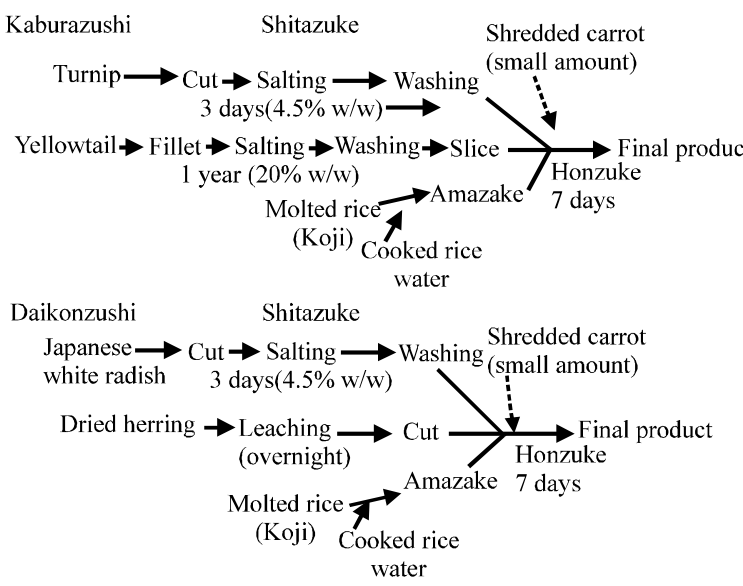

Fig. 3: Lactic acid bacteria and yeasts in decimal diluted kaburazushi observed by a phase-contrast microscope (ODEO Quatro, Iponacology). LB: Lactobacilli; LC: Lactococci

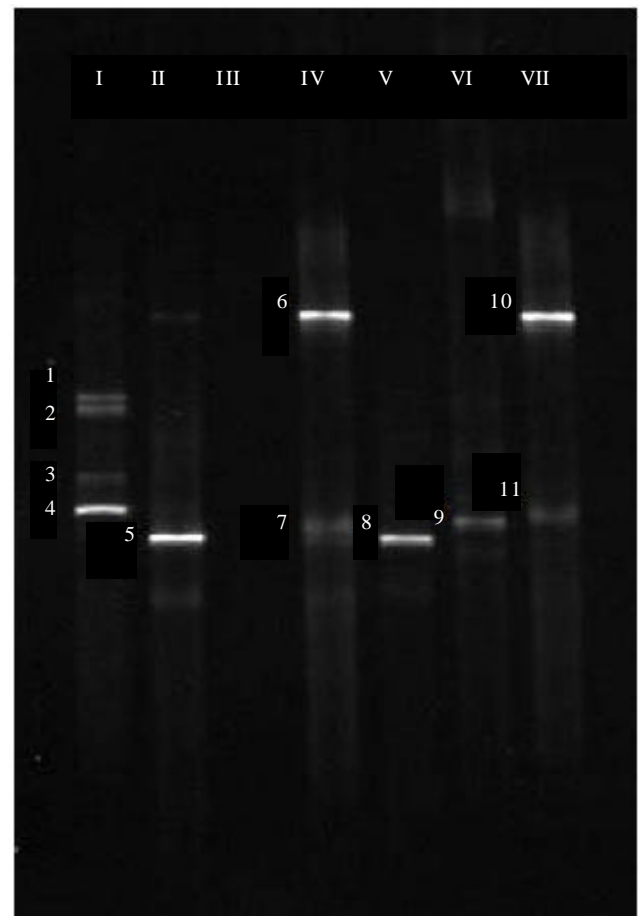

Fig. 4: DGGE analysis of PCR-amplified 16S rDNA fragments from kaburazushi and daikonzushi. Lanes re as follows. I: amazake; II: salted turnip, III: yellowtail, IV: kaburazushi; V: salted radish; VI: dried and leached herring and VII: daikonzushi

Bacterial flora analyzed by PCR-SSCP: PCR-SSCP analysis enables DNA fragments of similar sizes to be separated according to their configuration (secondary
Table 2: Identities of cloned fragment obtained from DGGE analysis of kaburazushi and daikonzushi

\begin{tabular}{|c|c|c|c|}
\hline Sample & $\begin{array}{l}\text { DGGE band } \\
\text { number (Fig. 2) }\end{array}$ & Identification & Identity $(\%)$ \\
\hline \multirow[t]{4}{*}{ Amazake } & 1 & Bacillus subtilis & 99 \\
\hline & 2 & Bacillus subtilis & 99 \\
\hline & 3 & Oryzasativa *** & 98 \\
\hline & 4 & Bacillus subtilis & 100 \\
\hline Turnip* & 5 & Brassica ropa $a^{* * * * *}$ & 99 \\
\hline \multirow[t]{2}{*}{ Kaburazushi } & 6 & Lactobacillus sakei & 99 \\
\hline & 7 & Brassica ropa $a^{\text {***** }}$ & 99 \\
\hline Radish* & 8 & Shewanella baltica & 100 \\
\hline Herring *** & 9 & Shewanella baltica & 97 \\
\hline \multirow[t]{2}{*}{ Daikonzushi } & 10 & Lactobacillus sakei & 100 \\
\hline & 11 & Lactobacillus sakei & 100 \\
\hline
\end{tabular}

*Salted: ***Dried and leached; ***BBotanical chloroplast DNA

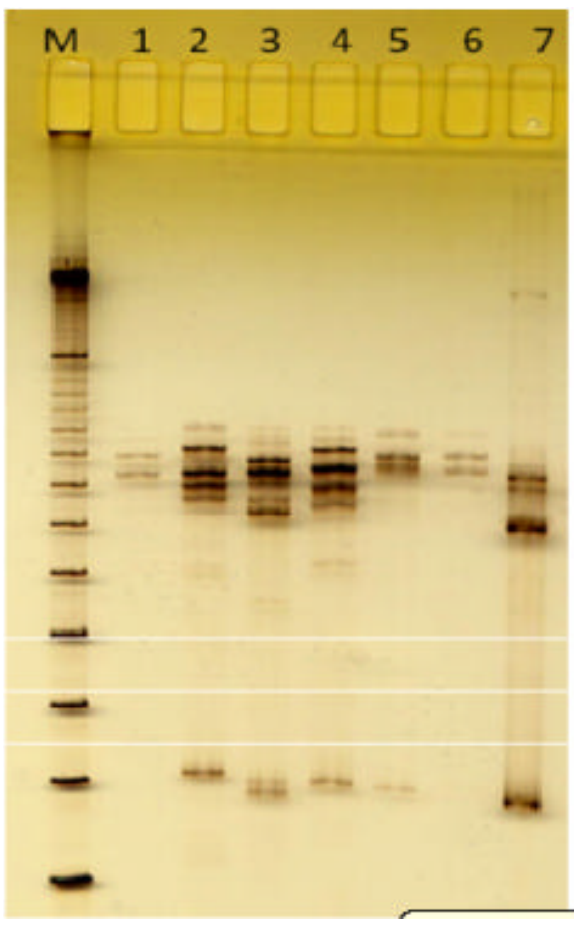

Fig. 5: SSCP analysis of PCR-amplified $16 \mathrm{~S}$ rDNA fragment patterns of selected isolates. Lanes are as follows. 1 and 10: Leuconostoc citreum; 2 and 12: Staphylococcus gallinarum; 3: Staph. kloosii; 4, 8, 9, 13, 16 and 19: Lactobacillus sakei, 5: Leu. gelidum; 6,11,17 and 20: Leu. mesenteroides and 7: Shewanella putrefaciens, 14: Stap. saprpphyticus; 15: Pseudomonas rhodesiae; 18: Kokuria

structure) (Hebenbrock et al., 1995). Targeting the 16S rRNA V3 region which permits phylogenetic discrimination of microbial species allows for $\mathrm{LAB}$ monitoring in the fermented food microbial community by one profile of bands (Fig. 5) where each band corresponds to a different sequence of the $16 \mathrm{~S}$ rRNA V3 region, i.e., one bacterium (Chamkha et al., 2008). As shown in Fig. 4 
Table 3: Identitification of isolates from kaburazushi and daikonzushi by PCR-SSCP analysis

\begin{tabular}{|c|c|c|c|c|}
\hline Samples & Culture media & $\begin{array}{r}\text { No. of } \\
\text { isolates }\end{array}$ & Identification & Identifity \\
\hline \multirow[t]{4}{*}{ Amazake } & TS & 11 & Staphylococcus gallinarum & 100 \\
\hline & & 1 & Staphylococcus kloosii & 100 \\
\hline & $\mathrm{TS}+10 \% \mathrm{NaCl}$ & 12 & Staphylococcus gallinarum & 100 \\
\hline & MRS & 9 & Leuconostoc citreum & 100 \\
\hline \multirow[t]{11}{*}{ Turnip* } & TS & 4 & Leuconostoc gelidum & 100 \\
\hline & & 2 & Leuconostoc mesenteroides & 100 \\
\hline & & 2 & Lactobacillus sakel & 100 \\
\hline & & 2 & Pseudomonas sp. & 90 \\
\hline & & 1 & Pseudomonas fluorescens & 100 \\
\hline & & 1 & Shewanella putrefaciens & 100 \\
\hline & $\mathrm{TS}+10 \% \mathrm{NaCl}$ & 5 & Psychrobacter adeliae & 99 \\
\hline & & 4 & Staphylococcus gallinarum & 100 \\
\hline & & 3 & $\begin{array}{l}\text { Marinilactibacillus } \\
\text { psychrotolerans }\end{array}$ & 100 \\
\hline & MRS & 8 & Lactobacillus sakei & 100 \\
\hline & & 1 & Leuconostoc gelidum & 100 \\
\hline Yellowtail* & MRS & 2 & Lactobacillus sakei & 100 \\
\hline \multirow{6}{*}{ Kaburazushi } & TS & 8 & Lactobacillus sakei & 100 \\
\hline & & 4 & Leuconostoc mesenteroides & 100 \\
\hline & $\mathrm{TS}+10 \% \mathrm{NaCl}$ & 12 & Staphylococcus gallinarum & 100 \\
\hline & MRS & 8 & Lactobacillus sakei & 100 \\
\hline & & 3 & Leuconostoc mesenteroides & 100 \\
\hline & & 1 & Leuconostoc citreum & 100 \\
\hline \multirow[t]{10}{*}{ Radish* } & TS & 4 & Plantibacter flavus & 100 \\
\hline & & 2 & $\begin{array}{l}\text { Curtobacterium } \\
\text { flaccumfaciens }\end{array}$ & 100 \\
\hline & & 1 & Curtobacterium citreum & 100 \\
\hline & & 2 & Psychrobacter faecalis & 100 \\
\hline & & 2 & $\begin{array}{l}\text { Staphylococcus } \\
\text { saprophyticus }\end{array}$ & 100 \\
\hline & & 1 & Pseudomonas rhodesiae & 99 \\
\hline & $\mathrm{TS}+10 \% \mathrm{NaCl}$ & 10 & $\begin{array}{l}\text { Staphylococcus } \\
\text { saprophyticus }\end{array}$ & 100 \\
\hline & & 1 & Staphylococcus equorum & 100 \\
\hline & & 1 & Psychroloccus glasimcola & 100 \\
\hline & MRS & 3 & Lactobacillus sakei & 100 \\
\hline \multirow[t]{7}{*}{ Herring** } & TS & 6 & $\begin{array}{l}\text { Staphylococcus } \\
\text { saprophyticus }\end{array}$ & 100 \\
\hline & & 2 & Psychrobacter cibarius & 100 \\
\hline & & 2 & Kocuria rhizophila & 100 \\
\hline & & 1 & $\begin{array}{l}\text { Carnobacterium } \\
\text { maltaromaticum }\end{array}$ & 100 \\
\hline & & 1 & $\begin{array}{l}\text { Brachybacterium } \\
\text { paraconglomeratum }\end{array}$ & 100 \\
\hline & $\mathrm{TS}+10 \% \mathrm{NaCl}$ & 11 & Psychroloccus glasimcola & 100 \\
\hline & & 1 & Staphylococcus equorum & 100 \\
\hline \multirow[t]{2}{*}{ MRS } & & 9 & Lactobacillus sakei & 100 \\
\hline & & 1 & Leuconostoc mesenteroides & 100 \\
\hline \multirow[t]{6}{*}{ Daikonzushi } & TS & 7 & Lactobacillus sakei & 100 \\
\hline & & 4 & Leuconostoc mesenteroides & 100 \\
\hline & & 1 & Leuconostoc citreum & 100 \\
\hline & $\mathrm{TS}+10 \% \mathrm{NaCl}$ & 11 & Staphylococcus gallinarum & 100 \\
\hline & & 1 & Staphylococcus carmosus & 100 \\
\hline & MRS & 9 & Lactobacillus sakel & 100 \\
\hline
\end{tabular}

*Salted: **Dried andleached

and Table 3, a variety of bacteria were isolated. Several genera of LAB such as Leuconostoc, Lactobacillus and Carnobacterium were predominantly isolated by MRS and TS agar plates. On the other hand, Staphylococcus sp. and several marine and psychrotrophic bacteria, such as Marinolacto bacillus, Pseudomonas and Psychrobacter were isolated from TS $10 \% \mathrm{NaCl}$ agar plates.
Although, Leuconostoc citreum was detected in amazeke from the colony counts of MRS and TS agar plates (Table 1), Staphylococcus was regarded as dominant. In salted turnip the dominant bacteria were L. sakei. Marinolactobacillus psychrotolerans was detected only in the salted turnip. Although various bacterial groups were detected in salted radish, the viable count was not high. The results of viable counts and PCR-SSCP analysis suggest that the predominant bacteria in dried and leached herring are Staphylococcus saprophyticus. L. sakei was the predominant isolate in both kaburazushi and daikonzushi which was confirmed by the DGGE analysis. Leuconostoc mesenteroides was also predominant in these products.

\section{CONCLUSIONS}

In this study, researchers studied the bacterial flora of the traditional fermented foods kaburazushi and daikonzushi using PCR-DGGE and PCR-SSCP. In the PCR-DGGE analysis, L. sakei was detected as the predominant bacteria in the products. The results differed from previously reports using cultivation methods. However, in the case of salted, the bacterial band of PCR-DGGE analysis could not be detected, though the various bacteria were isolated and identified by PCR-SSCP analysis. Therefore, PCR-DGGE 21 analysis using V3 and other regions may be necessary. Isolation and biochemical investigation of $L$. sakei for the fermentation process and its food functional properties are now in progress.

\section{ACKNOWLEDGEMENT}

The researchers thank Mr. M. Shijimaya (President of Sijimaya-Hompo, Kanazawa, Ishikawa, Japan) for kindly providing kaburazushi and daikonzushi. This study was supported by a fund from the Ministry of Agriculture, Forestry and Fisheries for research and development projects promoting the new policies of Agriculture, Forestry and Fisheries (No. 2041).

\section{REFERENCES}

Aida, K. and T. Sumino, 2007. Various components and bacteria of kaburazushi and daikonzushi. J. Integr. 18: $145-152$.

Ammor, S., E. Dufour, M. Zagorec, S. Chaillou and I. Chevallier, 2005. Characterization and selection of Lactobacillus sakei strains isolated from traditional dry sausage for their potential use as starter cultures. Food Microbiol., 22: 529-538. 
Ben-Omar, N. and F. Ampe, 2000. Microbial community dynamics during production of the Mexican fermented maize dough pozol. Applied Environ. Microbiol., 66: 3664-3673.

Chamkha, M., S. Sayadi, V. Bru and J.J. Godon, 2008. Microbial diversity in Tunisian olive fermentation brine as evaluated by small subunit rRNA-Single strand conformation polymorphism analysis. Int. J. Food Microbiol., 122: 211-215.

Chen, H.C., S.Y. Wang and M.J. Chen, 2008. Microbiological study of lactic acid bacteria in kefir grains by culture-dependent and cultureindependent methods. Food Microbiol., 25: 492-501.

Don, R.H., P.T. Cox, B.J. Wain Wright, K. Baker and J.S. Mattick, 1991. Touchdown PCR to circumvent spurious priming during gene amplification. Nucleic Acid Res., 1914: 4008-4008.

Ercolini, D., P.J. Hill and C.E.R. Dodd, 2003. Bacterial community structure and location stilton cheese. Applied Environ. Microbiol., 69: 3540-3548.

Fontan, M.C.G., J. Lorenzo, S. Martinez, I. Franco and J. Carballo, 2007. Microbiological characteristics of Botillo, a Spanish traditional pork sausage. LWT-Food Sci. Technol., 40: 1610-1622.

Fujii, T., T. Nishi, M. Okuzumi, 2008. Chemical composition and microbial flora of funazushi, crucian carp fermented with rice. Yamawaki Stud. Arts Sci., 46: 90-103.

Gao, Y., S. Jia, Q. Gao and Z. Tan, 2010. A novel bacteriocin with a broad inhibitory spectrum produced by Lactobacillus sake $\mathrm{C} 2$, isolated from traditional Chinese fermented cabbage. Food Control, 21: 76-81.

Guo, Z., J. Wang, L. Yan, W. Chen, X. Liu, H. Zhang, 2009. In vitro comparison of probiotic properties of Lactobacillus casei Zhang, a potential new probiotic, with selected probiotic strains. LWT-Food Sci. Technol., 42: 1640-1646.

Hebenbrock, K., M.P. Williams and L.B. Karger, 1995. Single-strand conformation polymorphism using capillary electrophoresis with two-dye laserinduced fluorescence detection. Electrophoresis, 16: 1429-1436.

Ichishima, E., 2004. Invitation to Fermented Foods (Hakkou Shokuhin eno Shotai). Shokabo Publishing Co. Ltd., Tokyo, pp: 36-39.

Kilpi, E.E.R., M.M. Kahara, J.L. Steele, A.M. Philanto and V.V. Joutsjoki, 2007. Angiotensin I converting enzyme inhibitory activity in milk fermented by wild-type and peptidase-deletion derivatives of Lactobacillus helveticus CNRZ32. Int. Dairy J., 17: 976-984.
Kim, T.W., J.H. Lee, S.E. Kim, M.H. Park, H.C. Chang and H.Y. Kim, 2009. Analysis of microbial communities in doenjang, a Korean fermented soybean paste, using nested PCR-denaturing gradient gel electrophoresis. Int. J. Food Microbiol., 131: 265-271.

Komatsuzaki, N., J. Shima, S. Kawamoto, H. Momose and T. Kimura, 2005. Production of $\gamma$-Aminobutyric Acid (GABA) by Lactobacillus paracasei isolated from traditional fermented foods. Food Microbiol., 22: 497-504.

Kuda T., N. Kaneko, T. Yano and M. Mori, 2010. Induction of superoxide anion radical scavenging capacity in Japanese white radish juice and milk by Lactobacillus plantarum isolated from aji-narezushi and kaburazushi. Food Chem., 120: 517-522.

Kuda, T., A. Shouda, N. Morimura and M. Yokoyama, 1998. Microflora in kaburazushi and daikonzushi made in Kanazawa, Japan. Nippon Suisan Gakkaishi, 64: 1053-1059.

Kuda, T., R. Tanibe, M. Mori, H. Take, T. Michihata, T. Yano, H. Takahashi and B. Kimura, 2009. Microbial and chemical properties of aji-no-susu, a traditional fermented fish with rice product in the Noto Peninsula, Japan. Fish. Sci., 75: 1499-1506.

Lee, D.H., Y.G. Zo and S.J. Kim, 1996. Nonradioactive method to study genetic profiles of natural bacterial communities by PCR-single-strandconformation polymorphism. Applied Environ. Microbiol., 62: 3112-3120.

Lore, T.A., S.K. Mbugua and J. Wangoh, 2005. Enumeration and identification of microflora in suusac, a Kenyan traditional fermented camel milk product. Food Sci. Technol., 38: 125-130.

Masuda, S., H. Yamaguchi, T. Kurokawa, T. Shirakami, R.F. Tsuji and I. Nishimura, 2008. Immunomodulatory effect of halophilic lactic acid bacterium Tetragenococcus halophilus Th221 from soy sauce moromi grown in high-salt medium. Int. J. Food Microbiol., 121: 245-252.

Miambi, E., J.P. Guyot and F. Ampe, 2003. Identification, isolation and quantification of representative bacteria from fermented cassava dough using an integrated approach of culture-dependent and cultureindependent methods. Int. J. Microbiol., 82: 111-120.

Muyzer, G., E.C. de Waal and A.G. Uitterlinden, 1993. Profiling of complex microbial populations by denaturing gradient gel electrophoresis analysis of polymerase chain reaction-amplified gene coding for 16S rRNA. Applied Environ. Microbiol., 59: 695-700. 
Nakayama, J., H. Hoshiko, M. Fukuda, H. Tanaka and N. Sakamoto et al., 2007. Molecular monitoring of bacterial community structure in long-aged nukadoko: Pickling bed of fermented rice bran dominated by slow-growing lactobacilli. J. Biosci. Bioengi., 104: 481-489.

Nakazawa, K., 1983. Geographical studies on the regional old dishes: an example of kaburazushi and daikonzushi. Bull. Dep. Geograp. Ochanomizu Univ., 25: 45-50.

Neefs, J.M., Y.L. Hendriks Van de Peer and R.D. Wachter, 1990. Compilation of small ribosomal subunit RNA sequences. Nucleic Acids Res., 18: 2237-2317.

Pennacchia, C., E.E. Vaughan and F. Villani, 2006. Potential probiotic Lactobacillus strains from fermented sausages: Further investigations on their probiotic properties. Meat Sci., 73: 90-101.

Riebroy, S., S. Benjakul and W. Viessanguan, 2008. Properties and acceptability of Som-fug, a Thai fermented fish mince, inoculated with lactic acid bacteria starters. LWT-Food Sci. Technol., 41: 569-580.

Sheffiedld, V.C., D.R. Cox, L.S. Lerman and R.M. Myers, 1998. Attachment of a 40-base-pair G+C-rich sequence (GC-clamp) to genomic DNA fragments by the polymerase chain reaction results in improved detection of single-base changes. Proc. Natl. Acad. Sci. USA., 86: 232-236.

Singh, S., P. Goswami, R. Singh and K.J. Heller, 2009. Application of molecular identification tools for Lactobacillus, with a focus on discrimination between closely related species. LWT-Food Sci. Technol., 42: 448-457.
Takahashi, H., B. Kimura, M. Yoshikawa, S. Gotou, I. Watanabe and T. Fujii, 2004. Direct detection and identification of lactic acid bacteria in a food processing plant and in meat products using denaturing gradient gel electrophoresis. J. Food Prot., 67: 2515-2520.

Urso, R., K. Rantsiou, C. Cantoni, G. Comi and L. Cocolin, 2006. Technological characterization of a bacteriocin-producing Lactobacillus sakei and its use in fermented sausages production. Int. J. Microbiol., 110: 232-239.

Vinderola, G., B. Capellini, F. Villarreal, V. Suárez, A. Quiberoni and J. Reinheimer, 2008. Usefulness of a set of simple in vitro tests for the screening and identification of probiotic candidate strains for dairy use. LWT-Food Sci. Technol., 41: 1678-1688.

Vinderola, G., C. Matar, J. Palacios and G. Perdigón, 2007. Mucosal immunomodulation by the nonbacterial fraction of milk fermented by Lactobacillus helveticus R389. Int. J. Food Microbiol., 115: 180-186.

Vogel, B.F., K. Venkateswaran, M. Satomi and G. Lone, 2005. Identification of Shewanella baltica as the most important $\mathrm{H} 2$ S-producing species during iced storage of Danish marine fish. Applied Environ. Microbiol., 71: 6689-6697.

Weisburg, W.G., S.M. Barns, D.A. Pelletier and D.J. Lane, 1991. 16S ribosomal DNA amplification for phylogenetic study. J. Bacteriol., 173: 697-703. 